\title{
Tanulhatóak-e a fogalmak? Álláspontok a megismeréstudomány egy nevezetes vitájában
}

\section{Bevezetés: a fogalomtanulás paradoxonjai}

Jerry Fodornak a fogalomtanulás elméleteivel kapcsolatos nevezetes kritikája az idók során többféle formát is öltött. A korai változat szerint (Fodor, 1975, 1981) minden tanulási jelenség végsó soron

hipotézis-vizsgálat jellegú, illetve hipotézis-vizsgálatra vezethetó vissza. Ahhoz viszont, hogy megfogalmazzunk egy hipotézist, minden fogalommal rendelkeznünk kell, melyet az magában foglal. Ezért a tanulás folyamán evidenciát gyújthetünk egyes hipotézisek mellett vagy ellen, de új fogalmakat nem sajátíthatunk el. Eddig ez az érv szoros rokonságot mutat Platón egy klasszikus példájával: ha az erény fogalmát szeretnénk megérteni, akkor példákat kell gyújtenünk az erény megnyilvánulására (ti. erényes cselekedetekre), és ki kell emelnünk ezekbôl valamiféle lényegi közös elemet. Igen ám, de ha elözetesen nem rendelkeznénk az erény fogalmával, már a gyújtést sem tudnánk elkezdeni (Platón, 2013). ${ }^{1}$

E z a fodori érv azonban rögvest pontosítást is igényel: különbséget kell tennünk összetett (strukturált) illetve egyszerü (primitív) fogalmak között. Nem biztos, hogy ez a különbségtétel minden, a fogalmakra vonatkozó elméletben érvényes, de Fodor felfogásában egyértelműen igen. Fodor mentális reprezentációelméletében a kompozicionalitásnak központi szerepe van: eszerint a reprezentációs szempontból tagolatlan, primitív fogalmak kombinációi eredményezik a komplex fogalmakat. Egy igen egyszerü példa erre a FEHÉR HOLLÓ ${ }^{2}$ összetett fogalma, amely a FEHÉR és a HOLLO fogalmainak konjunkció útján való összekapcsolásából jön létre. Ha viszont azt az állítást (hipotézist) szeretnénk megvizsgálni, hogy ,A fehér hollók ritkák', és elfogadjuk, hogy e kéttagú konjunkció képzése önmagában egy új fogalom tanulásának felel meg, akkor egyértelmü, hogy hipotézisek felállítása lehetőséget ad új fogalmak tanulására. Ez a példa, tehát a FEHÉR HOLLÓ fogalmának megtanulása, persze nevetségesen egyszerü, de mégse becsüljük le: vannak ugyanezen az elven müködő jóval komplexebb esetek, amiket intuitíve hajlamosak vagyunk a tanulás normál eseteinek tekinteni. Ilyen például a következő szabály megjegyzése és alkalmazása: „A király a kiválasztott bástya felé lép két mezőt, a kiválasztott bástya pedig a király által átlépett, tehát a királlyal szomszédos túloldali mezőre kerül" - vagyis a sáncolás a sakkban. Fodor korai felfogása szerint tehát a primitív, más fogalmakra már nem bontható fogalmak nem 
tanulhatóak - épp azért, mert nincs miből megkomponálni őket. E fogalmak Fodor szerint örökletesen adottak kell legyenek. Fodor ugyanakkor amellett is érvel, hogy hétköznapi és tudományos fogalmaink túlnyomó többsége primitív fogalom. Ebből viszont az a következtetés adódik, hogy fogalmaink szinte mindegyike öröklött, és a fogalomtanulás csak valami olyasmit jelent, mint madaraknál az imprinting, tehát hogy az örökletesen adott mentális reprezentáció valamely jellegzetes környezeti hatásra aktiválódik, megjelenik. Ezt Fodoron kívül szinte mindenki más elfogadhatatlannak tartotta (finoman szólva), hiszen, ha belegondolunk, az is következik belöle, hogy mondjuk Platón vagy Arisztotelész is rendelkezett a KARBURÁTOR fogalmával, csak ez a fogalom az ő elméjükben soha nem aktiválódott. ${ }^{3}$ Fodor korai érve tehát létrehozott egy paradoxont: a konklúzió elfogadhatatlan, azonban az érvre sokáig nem sikerült hathatós választ adni (ti. meggyőző elmélettel előállni a fogalomtanulásról).

Néhány évvel ezelőtt azonban Fodor (2008) úgy találta, hogy még korai következtetései is túl gyengék voltak, ezért újrafogalmazta fogalomelsajátítással kapcsolatos érvét. Az új gondolatmenet szerint nem az a fogalomtanulás akadálya, hogy fogalmaink nagyrésze primitív, hanem az, hogy a kompozicionalitás elve (vagyis hogy összetett mentális reprezentációink egyszerübb elemekből, adott kombinációs szabályok által jönnek létre) nem képes számot adni a mentális rendszerek kifejezőerejének növekedéséről. A kifejezöerö fogalma a formális logikából ered; egy formális nyelv esetében azoknak az összetett fogalmaknak, hipotéziseknek, illetve elméleteknek az összessége, amelyek az adott formális nyelv elemi szimbólumai és ezek kombinációs szabályai segítségével kifejezhetőek. Például a nulladrendü logika, mely csak állítások közti viszonyokat vizsgál, nem képes a számok fogalmainak kifejezésére, sem kvantifikációra. Frege azonban bebizonyította, hogy megfelelően konstruált, az állítások belső szerkezetét is vizsgáló, kvantorokat is tartalmazó logikai rendszerek képesek az aritmetikai összafüggések kifejezésére (Frege 1967, 1974) - akkor tehát, ha ezeket az új alapelemeket (pl. kvantorokat; állításfüggvényeket) hozzáadjuk a rendszerhez. A klasszikus predikátumlogika rendszere ugyanakkor nem képes a lehetöség illetve szükségszerüség fogalmainak kifejezésére; ezeket ismét új alapelemekként kell bevezetnünk, és ez vezet el a modális logikához. ${ }^{4}$ Vannak sokkal hétköznapibb példák is a kifejezőerő különbségeire. Ha valaki nem rendelkezik például a HEGEDÜ fogalmával, akkor nem képes a hegedűkről, mint olyanokról gondolkodni és beszélni. Ennek egy szépirodalmi illusztrációja Karinthy Frigyes: $A$ hegedü címü novellája, melyben a maori bennszülöttek kulacsnak, majd kavicstartó doboznak, később dísznek, illetve totemnek néznek egy utazók által ottfelejtett hegedüt - minthogy „fogalmuk sincs róla”, mi is az valójában.

A kogníciónak és ezen belül a tanulásnak legtöbb mai elmélete a kompozicionalitásra épül: arra az elvre tehát, hogy egyszerübb mentális reprezentációkból komplexebbeket építünk föl valamilyen kombinációs szabályok segítségével, illetve az alapelemek bizonyos paramétereit beállítjuk. A perceptuális prototípusok, kognitív sémák, szkriptek mentális modellek, perceptuális szimbólumrendszerek, vagy a propozicionális reprezentáció elméletei (pl. Fodor, 1975, 1998, 2008; Rosch, 1975; Rosch \& Mervis, 1975; Minsky, 1975; Rumelhart, 1980; Schank \& Abelson, 1977; Johnson-Laird, 1983, 2006; Barsalou, 1999; Carey, 2009) mind támogatják ezt az általánosítást. ${ }^{5}$ Ha tehát a kogníció mechanizmusainak alapja a kompozicionalitás, akkor a tanulás Fodor szerint nem érhet el mást, mint a velünk született fogalmi kapacitások manifesztációját. Csak annak kifejezésére vagyunk képesek, aminek a reprezentációs alapelemeivel örökletesen rendelkezünk; más szóval csak biológiailag meghatározott reprezentációs alapelemeink rekombinálására vagyunk képesek a tanulás során. A logikában meglévő formális korlátok érvényesek a mentális reprezentáció kompozicionalitásra alapuló világában is. A fogalomtanulás igazi kritériuma a kifejezőerő növekedése lenne, ezt viszont a 
kompozicionalitás nem képes produkálni, így a fogalomtanulás gondolata inherensen ellentmondásos. A pszichológia Szent Grálja tehát elérhetetlen.

Egy megjegyzés: Az előbbiekben említett példa, a HEGEDÜ fogalma egyértelmüen elsajátítható, ám ez önmagában nem cáfolja a fenti gondolatmenetet, hiszen a fogalom manifesztációja, megjelenése valamely személy esetében önmagában nem bizonyítéka a tanulásnak. Lehet, hogy a személy már elözetesen is rendelkezett e fogalommal egy rejtettebb formában, ami nélkül nem lett volna képes olyan gyorsan megérteni (ahogy egy tipikus néhány éves gyerek képes), hogy mi is a hegedü. Az mélyebb kérdés itt tehát az, hogy a hegedükkel kapcsolatos nem túl sok érzékleti tapasztalat hogyan vezet el, legtöbbünk esetében el igen gyorsan, e tárgy absztrakt lényegének megragadásához így többek között ahhoz, hogy nem minden hegedü, ami annak néz ki, és nem is minden hegedü néz ki „hegedüszerüen” (1. az 1. ábrát).

A probléma tehát adott: a kogníció egy olyan elméletének felállítása, amely túllép a hagyományos kompozicionalitás eme korlátain, és megmagyarázza a kifejezőerő növekedését. A továbbiakban egy ezzel a kérdéssel kapcsolatos vitát tekintek át, melyben az innátista oldalt Fodor mellett Georges Rey (2013) képviseli, a tanuláselméleti válaszokat pedig Susan Carey $(2009,2014,2015)$ illetve Eric Margolis és Stephen Laurence (Margolis, 1999; Margolis \& Laurence, 2011). Végül fel fogok vetni néhány ötletet, melyek kiindulópontként szolgálhatnak egy fogalomtanulási elmélet számára, $\mathrm{s}$ így a fodori kihívás megválaszolására.

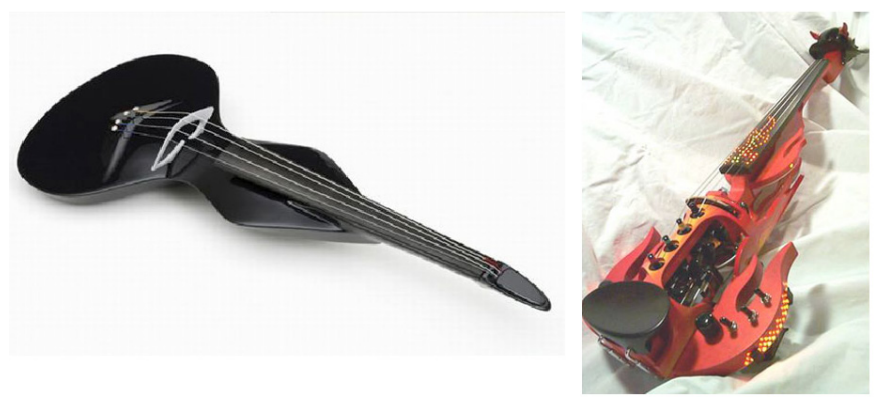

1. ábra. Két nehezen felismerhetö hegedü

\section{Kiútkeresés}

\section{Primitív fogalmak tanulása}

A fogalmak természetére, mibenlétére vonatkozóan számos pszichológiai elmélet született, és ezekre az elméletekre huszadik században kibontakozott nyelvfilozófia is jelentős hatással volt. A filozófia jótékony hatásának köszönhetően - jórészt az utóbbi évtizedekben - került egyre inkább a pszichológiai kutatás látókörébe a referencia problémája, az tehát, hogy a fogalmak alapvető funkciója a mentális rendszerek külvilágban való lehorgonyzása. A pszichológia eredményei ugyanakkor segítettek néhány, a fogalmakkal kapcsolatos filozófiai paradoxon tisztázásában. A megismeréstudomány uralkodó felfogása szerint a fogalmak mentális reprezentációk, melyek az észlelésen és viselkedésen keresztül állnak kapcsolatban a külvilággal, miközben a gondolkodásban, következtetéseinkben is központi szerepet töltenek be. Fogalmaink jelentését egyfelöl az határozza meg, hogy milyen következtetésekre adnak alapot, vagyis hogyan bővítik tudásrendszerünket, másfelől viszont az, hogy mi a referenciájuk, azaz miről szólnak. E 
kettő közül a referencia az elsődleges: egy fogalom megalapozása során először azt kell rögzítenünk, hogy miről gondolkodunk, illetve beszélünk, és ezt követően bővíthetjük a

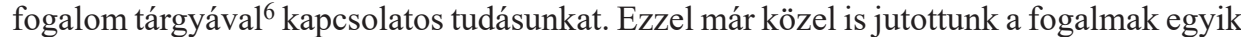
fontos mai elméletéhez, az ún. mentális mappa elmélethez (Fodor, 1998, 2008; Margolis, 1999; Carey, 2009, 12. fejezet; Recanati, 2013). ${ }^{7}$ Eszerint a fogalmak olyan mentális reprezentációk, melyek egy szemantikai szempontból tagolatlan, primitív szimbólumból, és egy ahhoz kapcsolódó „memóriahelyból” vagy mentális mappából állnak. A primitív szimbólum szerepe az, hogy a fogalom tárgyához való oksági kapcsolódás alapja legyen, tehát lehetővé tegye a referenciát. A mappa pedig a referenciával kapcsolatos ismereteinket tárolja - ez lehet absztrakt ismeret, mely más fogalmak segítségével való leírásokat tartalmaz, de lehet az észlelésből származó tapasztalat is. Amikor valaki először kezd használni egy új fogalmat, akkor a hozzá tartozó mappa még szinte teljesen üres, vagyis a személy fogalommal kapcsolatos ismeretei általában szükösek, és csak később bővülnek fokozatosan. Ebben az értelemben - tehát hogy az adott fogalomhoz tartozó mentális mappánkat feltöltjük ismeretekkel - a fogalmak egyértelmúen tanulhatóak, ezzel még a radikális innátisták is egyetértenek. Jellegzetesen ez történik például tanár és diák között egy oktatási helyzetben: először rögzítik, hogy miről beszélnek (pl. az emlősökről, vagy az elektromágneses térről), aztán a tanár igyekszik a diák ismeretrendszerét bővíteni. Ez tehát nem kérdés; a kérdés az, hogy a fogalom megalapozása szempontjából elsődleges referencia rögzítése hogyan történik. Ennek sokféle módja lehet, akár egy személyen belül is. Ha például valaki nem tudja megkülönböztetni az aranyat a sárgaréztől, attól még rendelkezhet az ARANY fogalmával, vagyis, ennek szükséges feltételeként képes lehet e fogalom és a hozzá tartozó nyelvi kifejezés referenciáját elérni, mondjuk szociális úton („Amikor az 'arany' szót használom, arra a sárga fémre gondolok, amit egy ötvös vagy vegyész aranyként azonosítana.”). Ezt a másokra, nálunk tapasztaltabbakra hagyatkozó referálási módot nevezik deferenciának (Putnam, 1975). Később a személy önállóan is megtanulhatja felismerni az arany megjelenési formáit. Az önálló referálásnak is többféle módja lehet; van, amikor az észlelésünkre hagyatkozunk, mert az is elég megbízható, van, amikor müszerekre, máskor pedig fogalmi kritériumokra, következtetésre. A referenciának tehát még egyetlen fogalom esetében is sokféle módja lehetséges.

Az eddig leírtakkal Fodor és a mentális mappa elmélet többi képviselöje is teljesen egyetért; a tanulhatóság problémái csak ezen a ponton, a referencia rögzítése kapcsán vetődnek föl. Amikor egy pár éves városi gyerek először lát tehenet, elöször vizuáis benyomásai, és a felnőttektől hallott nevek alapján tanulja meg megkülönböztetni más állatoktól. Bár ekkor még igen keveset tud a tehenekről, mégis nagy biztonsággal absztrahál abba az irányba, hogy a látott dolog egy állat, mely önállóan mozog, így és így viselkedik (bőg, legelészik, stb.). Ezzel egyben meg is tanulja a TEHÉN fogalmát. Ha azonban egy kicsit elvonatkoztatunk attól, ami a hétköznapi szemlélet számára természetesnek tünik, érdekes kérdések vetődnek föl. Amikor a gyerek a tehenet elöször látja, e látványból egészen más irányokban is általánosíthatna. Például a látott tehén színére, foltjainak mintázatára úgy, hogy később is hasonló színü-alakú foltokat keres, és esetleg a 'tehén' szót is ezekre alkalmazza - már ha talál ilyet. Ugyanígy a tehén valamely testrészére (szarvára, vagy a bal mellső lábára) is felfigyelhetne, és, ezt megjegyezve, később hasonló testrészekre lesz értékeny más helyzetekben. Esetleg a tehenet, a lovat, és a kettejük társaságában gyakran előforduló szekeret is azonos típusba sorolhatná, méretük és tipikus helyváltoztató mozgásuk alapján. Sőt, kialakuló fogalmát a hozzá kapcsolódó nyelvi címkével együtt az egyedi állathoz is rendelhetné, nem terjesztve ki azt a többi tehénre. Az absztrakció lehetséges irányainak száma végtelen; hogyan lehet, hogy a gyerekek mégis igen gyorsan megértik az ilyen típusfogalmakat? (A bevezetőben említett HEGEDÜ fogalom esete is igen hasonló.) A filozófus Nelson Goodman (1983) mutatott rá arra, hogy mennyire nem triviális tény azoknak az általánosításoknak a 
választása, amit a hétköznapi induktív következtetéseink során érvényesítünk. Ezt kissé más módon, a nyelv szavainak elsajátítása kapcsán fejtette ki W. v O. Quine (1960). Honnan tudhatja egy bennszülött törzs nyelvét vizsgáló antropológus, hogy egy nyúl megjelenésekor a vadász 'Gavagai' felkiáltása azt jelenti, hogy nyúl - hiszen annyi minden mást is jelenthet? ${ }^{8}$ Vegyük észre, hogy a reggelizőasztalnál ülö kétéves gyerek, aki mondjuk életében elöször hallja a 'bögre' szót, Quine antropológusához eléggé hasonló helyzetben van. Ez tehát az indukció problémája az egyszerü fogalmak tanulása esetén. Az pedig, hogy a gyerekek ilyen esetekben legtöbbször magabiztosan általánosítanak a ,jó” irányba, azt is jelentheti, hogy az ember által használt fogalmak tanulására egy specifikus öröklött pogramjuk van, esetleg imprinting jelleggel aktiválódnak a bennünk szunnyadó fogalmak.

Azt, hogy ilyen estekben mégsem specifikus fogalmakat kell örökölnünk (ami, valljuk be, intuitíve mégiscsak nehezen hihetö), úgy lehet a legjobban bizonyítani, ha érthetővé tesszük a nyelvet ill. fogalmakat tanuló gyerekek határozott irányokba mutató absztrakciós képességét. A Goodman és Quine-féle paradoxonok megoldásához a pszichológiai kutatás jelentős mértékben járult hozzá. Ellen Markman nevéhez füződik például a teljestárgy-korlát felfedezése: amikor a nyelvet tanuló gyerek egy új tárgyat lát, és ezzel egyidőben egy új szót is hall, akkor az új szót az egész tárgy, és nem valamely részlete nevének tekinti (Markman, 1990). Mint Markman és Hutchinson (1984) kimutatták, a nevek használata 4-5 éves gyerekek osztályozását tematikusból taxonomikus irányba tereli. Ha egy képen két különböző állatfigurát meg egy etetőtálat mutatunk, és az egyik állatra mutatva azt mondjuk: „Nézd csak, itt egy dax! Tudnál egy másik daxot mutatni?”, akkor a gyerekek többnyire a másik állatfigurára mutatnak, vagyis taxonomikusan osztályoznak (állat - állat). Ha viszont a kérdést az ismeretlen név használata nélkül tesszük föl ('Látod ezt? Tudnál egy másikat mutatni?'), akkor a kísérletvezető által jelzett állat mellé a 4-5 évesek inkább az etetőtálat mutatják, vagyis tematikusan kategorizálnak (állat - ennivaló). Ez a tendencia teljesen új, ismeretlen fajta tárgyakra is megnyilvánul, és nemcsak 4-5 éves korban, hanem már már másfél-kétéveseknél is (Backsheider \& Markman, 1990). Markman (1990) ugyancsak megfigyelte a kölcsönös kizárás elvét kisgyerekeknél: azt a heurisztikát, hogy minden tárgynak csak egy neve van. Ez általánosságben nyilvánvalóan hamis feltevés, de a szülö-gyerek kommunikáció kontextusában jó iránymutató. Ennek alapján a gyerekek, ha egy tárgyra vonatkozóan egy második nevet hallanak, akkor arra következtetnek, hogy a második kifejezés már nem az egész tárgy neve, hanem annak valamely részét vagy tulajdonságát jelöli. A tárgyak alakja központi szerepet játszik a típusazonosságban (Landau, Smith, \& Jones, 1998); egy piros kanál elfogadható kanálnak, de ha az alakja szokatlan, akkor kétségek merülhetnekek föl mibenlétét illetően. A jelentések tanulásában szerepe van a közös figyelemnek is: 10-12 hónapos kortól, tehát mire szavakat kezdenek tanulni, a gyerekek képesek mások tekintetét követve megállapítani, hogy azok hova néznek. Ez a képesség jól használható később, az új szavak hallásakor, hiszen a szülö jó eséllyel arra a dologra néz, amiröl beszél - legalábbis a szülö-gyerek kommunikáció során.

Még egy igen fontos felismerés, hogy a gyerekek nagyjából négyéves kortól kezdve egy sajátos „esszencialista” alapfeltevéssel élnek, az állatokkal és más, a természetben létező dolgokkal kapcsolatban. Ha egy cicára kutya maszkot teszünk, az attól nem lesz kutya, de attól sem, ha átfestjük a szőrét. Megértik tehát, hogy a dolgok külső megjelenése lehet félrevezető a természetüket illetőleg, mert a dolgok valódi természetét belső, nem feltétlenül látható tulajdonságaik határozzák meg. Iskoláskor elejére a gyerekek a természeti típusok (pl. tehén) illetve a mesterséges tárgyak (pl. hegedű) közti mélyebb különbségeket is megsejtik: a készített tárgyak lényegét használatuk módja, funkciójuk adja, míg a természeti fajták esetében tipikusan rejtett (fizikai, biológiai) 
tényezők a döntőek, melyek általában a felszíni vonásokat meghatározzák (Keil, 1989; Gelman, 2005).

Ezek a megfigyelések jól illeszkednek a fogalmak mappaelméletéhez: a mentális mappa tartalmazhat egy „esszencia rubrikát”, tehát annak feltételezését, hogy a gyors felismerést szolgáló (de néha félrevezető) érzékelhető tulajdonságokon túl vannak elvontabb, estenként rejtett, tulajdonságok, melyek megismerése elvezet a valódi kategóriákhoz és referenciához (Margolis \& Laurence, 2011). Maga az esszencialista feltételezés már elégséges kiindulópont a fogalomtanuláshoz; az esszenciarubrikát tényleges tudással ráér később is feltölteni. Az észlelhető tulajdonságok a fogalmi esszenciához képest csak heurisztikus jellegü, többnyire megbízható jelzések. Összefoglalva tehát, nem az egyes fogalmakat kell örökülnünk, hanem egy általános fogalmi sémát, amely, a mentális mappaelmélet szerint egy referenciarögzítő elemből (vagy primitív szimbólumból, tagolatlan mentális reprezentációból) és egy ehhez kapcsolt tudástároló részből áll, mely külön tudja választani a felismerést segítő, illetve elvontabb, de alapvetőbb tulajdonságokat. Így egyetlen általános fogalmi séma segítségével sok új fogalmat tanulhatunk meg, és ezen az úton mentális rendszerük kifejezőereje is növekedhet.

\section{Elméleti fogalmak és quine-i csizmahúzás}

A gyerekeknek azonban még a típusfogalmaknál is komolyabb absztrakciókkal kell elboldogulniuk már 4-5 évesen, illetve később, iskoláskorban. Az egyik első ilyen absztrakció a számok (egész számok) fogalma, amit, egy bizonyos szinten már a tipikus 4-5 éves gyerekek is értenek. Évekkel később a törtek, a számrendszerek, vagy a fizika, kémia fogalmai még nagyobb kihívások elé állítják őket. E fogalmak megtanulása már komolyabb mentális erőfeszítést igényel a gyerekektől, mint a TEHÉN vagy a HEGEDÜ elsajátítása; ez utóbbiak a korai intenzív szótanulási szakaszban (másfél-kétéves kortól kezdődően) sokkal könnyebben, gyorsan, automatikusan megtörténnek. Ugyanakkor az absztakt fogalmak megjelenése szintén fölveti az innátizmus kérdését. Tudjuk például, hogy bizonyos egyszerü mennyiségfogalmakkal már állatok is rendelkeznek, az egész számok fogalmával azomban még emberszabású rokonaink sem. ${ }^{9}$

Susan Carey (2009) szerint e második, absztraktabb fogalomosztály elsajátításának módja az általa Quine-féle csizmahúzásnak (Quinian bootstrapping) nevezett mechanizmus. ${ }^{10}$ Ennek kiindulópontja Carey szerint az, hogy a csecsemők rendelkeznek bizonyos absztrakt „proto-fogalmakkal” - Carey ezek összességét jelöli a 'core cognition' kifejetéssel, amit magyarul talán magkogníciónak nevezhetnénk. Ennek számos példája van: a csecsemők néhány hónapos kortól képesek analóg, közelítőleges nagyságbecslésre; még egy éves kor előtt pontosan követni tudják háromnál nem nagyobb elemszámú halmazok számosságát, rendelkeznek tárgyfogalommal, érzékenyek az oksági összefüggések látható jeleire (pl. a véletlen mozgásokkal szemben), illetve az ágencia (pl. önindította mozgás, célorientáció) jeleire is. A későbbiekben a magkogníciós rendszer beépítésével eljutnak a felnőttkori absztrakt fogalmakhoz. Ennek két tapasztalható jele van gyerekeknél: egyrészt egy adott fogalmi körön belül egy bizonyos életkorban javul a teljesítmény (több különböző feladatban egyszerre), ugyanakkor a gyerekek számára észrevehetően nehéz (gyakran mentális erőfeszítést igényel) ezeket a fogalmi váltásokat elérni. A quine-i csizmahúzás mechanizmusa két nagy lépést foglal magában: először új szimbólumok jelentés nélküli kombinációját tanuljuk meg, utána pedig ezt egyfajta analógiás érvelés segítségével értelmezzük, jelentéssel ruházzuk föl. E bonyolult folyamat Carey által legalaposabban kidolgozott példája az egész számok fogalmának elsajátítása. A gyerekek jó része már két-három éves korban kívülről tudja a számneveket (a megfelelő sorrendben), de a számolás megtanulásához még két dologra van szükség: 
a számnevek elsorolása és a leszámolandó halmaz elemeire való rámutatatások közötti egy-az-egyhez hozzárendelésre (mindegyikre pontosan egyszer mutatunk), valamint az ún. kardinalitási elv megértésére, tehát hogy az egyes számnevek nem a halmaz egyes elemeit jelölik, hanem az adott pontig leszámolt részhalmaz számosságát (így az utolsó számnév az egész halmazét). Tehát az eredetileg „vers jelleggel” megtanult szimbólumsor ('egy, kettő, három...') úgy nyer jelentést, hogy hozzákapcsolódik az egymást követő (az előzőnél eggyel nagyobb) számosságú hamazok sorozatához. Ez utóbbi folyamat kiindulópontja a már csecsemőkortól meglévő képesség a legföljebb háromelemü halmazok pontos reprezentációjára; ennek alapján értik meg a négyötévesek, hogy vannak nagyobb halmazok is.

Egészében a quine-i csizmahúzás - legalábbis Carey (2009, 12-13. fejezet) véleménye szerint - túllép a kompozicionalitás elvén (bár a jelentés nélküli szimbólumsorok konstruálása önmagában még nem), és így megmutatja, hogy (i) a fogalomtanulás nem szükségeszerủen ölti hipotézisvizsgálat formáját, illetve (ii) a kompozicionalitás elvétől eltérő folyamatokat tartalmaz. Az analógiás érvelés e formája által pedig új fogalmi primitívek jönnek létre, vagyis növekszik a kognitív rendszer (jelen esetben a fejlődő gyermeki elme) kifejezőereje.

\section{Quine-i csizmahúzás: egy innátista kritika}

A filozófus Georges Rey (2013) szerint a quine-i csizmahúzás elve nem ad meggyőző magyarázatot a kifejezőerő növekedésére, ugyanis a fodori cirkularitási probléma (ti. hogy a fogalomtanulás alapjául szolgáló hipotézisben már szerepelnie kell a megtanulandó fogalomnak) egy új formában jelenik meg a Carey-féle elgondolásban. Ez igen jól bemutatható az egész számok elsajátításának fönti példáján. Az egészszám-fogalmak elsajátításának kulcsfontosságú lépése annak felismerése, hogy a számnevek halmazok (tkp. halmaz típusok: pl. öt kiskutya; öt kanál, stb.) olyan sorozatát nevezik meg, ahol a sorozat következő tagja eggyel több elemet tartalmaz, mint a megelőző. A felismerendő analógia tehát a következő számnév és a következö halmaz között áll fenn: a következö halmaz mindig eggyel nagyobb elemszámú az előzőnél. Ehhez az általánosításhoz azonban, mint Rey rámutat, szükség van az EGGYEL NAGYOBB, MINT, másképpen a KÖVETKEZÖ EGÉSZ SZÁM fogalmára - enélkül a fogalom nélkül a gyerek sorba se tudná rendezni a halmazokat a megfelelő módon. A kör tehát bezárul: Carey elméletéből az következik, hogy az EGÉSZ SZÁM fogalmának elsajátításához az EGÉSZ SZÁM fogalmával kell már elözetesen rendelkezni.

Kicsit általánosabb szinten Rey arra is rámutat, hogy az analógiaképzésre hivatkozni önmagában nem elégséges a fogalomtanulás magyarázatához, ugyanis számos esetben a fogalmak „tanulása” olyan felszínes, általános analógiák segítségével történik, melyek egyáltalán nem teszik érthetövé, hogy hogyan konstruáljuk meg elménkben az elsajátítandó absztakt fogalmat. Sőt általában ahhoz, hogy két jelenség között analóg viszonyt ismerjünk föl, mindkettőről elözetesen valamilyen fogalommal kell rendelkeznünk; csak létező fogalmak között találhatunk párhuzamokat, s így az analógiaképzés nem is lehet az új fogalmak tanulásának kulcsmozzanata. Rey példája az analógiák eme erőtlenségére a következő (Rey, 2013). Egyetemi fizika kurzusokon az általános relativitáselmélet bevezetőjeként néha előkerül a következő analógia: „A négydimenziós tér görbülete olyan, mint egy gumilemez, melyet a gravitáció hatására benyom egy rajta gördülő nehéz fémgolyó. Kivéve, hogy nincs gumilemez, se fémgolyó, se gravitáció, és a benyomódás négydimenziós." Kis túlzással, ebből csak az érti meg a négydimenziós tér görbületének fogalmát, aki már addig is tudta, miről van szó. Az analógiák tehát, Rey szerint, segíthetnek egy fogalom aktiválódásában (imprinting jelleggel), de a tanulást, a megkonstruálás értelmében, nem eredményezhetik. 


\section{Válaszok Rey kritikájára}

Az előző részben röviden összefoglalt kritikákra többféle választ is lehet adni. Carey (2014, 2015) maga is megtette ezt, és az ő szempontjait továbbiakkal is ki lehet egészíteni. Ami a RÁKÖVETKEZÖ SZÁM fogalmát illeti, megmutatható, hogy a magkogníció Carey (2009) által feltételezett elemeiből, és némi szenzomotoros tapasztalatszerzésből levezethető a RÁKÖVETKEZÖ SZÁM fogalmának egy viszonylag absztrakt formája (Jakab, 2013). Igen röviden, a gyerekek például különböző tárgyak (pl. kék és piros Lego kockák; lovak és lovasok) párosítgatásából (azaz egy-az-egyhez hozzárendeléséből) leszámolás nélkül megkonstruálhatják az egyenlőség fogalmát: a lovak és lovasok száma egyenlö, ha mindegyiknek jut pár, azaz nincs lovas ló nélkül, se ló lovas nélkül. Ezután rájöhetnek arra is, hogy ezt a szituációt a legkisebb erőfeszítéssel úgy lehet „elrontani”, ha egyetlen lovat (vagy lovast) adunk a megfelelő halmazhoz. Sőt, ezt a legkisebb elrontást bármekkora halmazokkal megtehetjük, tehát ez egy általánosítható müvelet. Ilyen esetben a lovak és lovasok halmazának nagysága között lesz egy minimális különbség. Ilyen és hasonló tapasztalatok alapján el lehet jutni a RÁKÖVETKEZÖ SZÁM fogalmának egy olyan formájáig, amely a négy-ötéves gyerekek viselkedését kielégítően magyarázza. Carey (2014) a következőképpen oldja meg ugyanezt a problémát. Egy gyermek, aki a számneveket már ismeri (legalább valameddig) arra jöhet rá, hogy ha leszámol egy adott halmazt, melynek eredményeként eljut egy számnévig, majd hozzátesz a halmazhoz egyetlen elemet, és azt újra leszámolja, akkor a számnevek sorában a következőhöz jut el. Ez még nem a RÁKÖVETKEZÖ SZÁM absztrakt matematikai definíciója, de nem is tételezi azt föl örökletes fogmában, és szintén segít megmagyarázni a négyötéves gyerekek számolással kapcsolatos teljesítményét. Ezekkel a válaszokkal tehát megtörhető a cirkularitás; az EGÉSZ SZÁM fogalmának megtanulásához nem kell ennek a fogalomnak már előzetesen adottnak lennie.

Az analógiákkal kapcsolatban megjegyzendő, hogy vannak egyszerübb esetek, amikor elég tisztán látható, hogy egy analógiaképzés során a pár egyik tagját mégiscsak megkonstruáljuk. A porlasztó feltalálójáról, Csonka Jánosról ismert a következő anekdota (Vajda, 1943, p. 176): amikor Bánki Donáttal közösen az üzemenyag adagolásának új lehetőségét kutatták, egyszer a Nemzeti Múzeum előtt sétálva Csonka észrevett egy virágárus lányt, aki fúvópalackkal permetezte virágait. Azonnal rájött, hogy e módszer megfelelö lesz a benzinmotorokban is, és fel lehet vele váltani az 1800-as évek végén használt párologtatásos módszert, ami alacsony hatékonyságú és balesetveszélyes is volt. A fúvópalack képzeletbeli, majd valóságos ,átszerkesztéséből” megszületett a porlasztó. Ez az eset tehát egy példa segítségével mutatja meg, hogy az analógiás gondolkodás elvezethet új fogalmak megkonstruálásához is - még ha nem is minden analógia esetén történik ez meg.

Carey $(2014,2015)$ arra is rámutatott, hogy az innátisták által hangsúlyozott különbség egy fogalom birtoklása (possession) és megjelenése (manifestation) között egy súlyos kétértelmüséget takar. Az innátisták szerint a fogalmakkal örökletesen rendelkezünk, és az elsajátítás során valamiképpen aktiváljuk őket - innentől kezdve használhatóak a gondolkodás során. Az elsajátítás az innátista felfogás szerint vagy imprinting-szerü aktiváció, vagy egyszerübb elemekbőlkombinációs szabályokalapján valómegkonstruálás, de semmiképpen sem olyan folyamat, amely a kifejezőerő növekedéséhez vezet. De mit is jelent pontosan egy fogalom megjelenés elötti birtoklása? Ezt meghatározhatjuk úgy, hogy minden olyan fogalmat birtoklunk, melynek a manifesztációjára képesek vagyunk. Ezt azonban még egy empirista is elfogadhatná, aki amúgy azt gondolja, hogy valamennyi fogalmunkat néhány általános, örökletesen adott szerveződési elv (például érzékleti benyomásaink közötti asszociációk) segítségével építjük föl. Valójában a fogalom- 
birtoklás helyes innátista megfogalmazása valami olyasmi lehetne, hogy biológiai folyamatok (öröklés és érés) által rögzített reprezentációs primitívek illetve struktúrák léteznek agyunkban-elménkben, és ezeket csak előhívjuk, de nem megkonstruáljuk az elsajátítás során. Kritikájában Rey nem tesz különbséget e két meghatározás között, ehelyett az elsőt használja. Abban azonban Carey válaszában igazat ad Rey-nek, hogy egyáltalán nem világos, milyen logikai-kombinációs erőforrásokkal rendelkeznek a csecsemők, így ez a terület intenzív kutatásokat igényel.

\section{Egy példa és egy elv a kifejezőerő növekedésére}

Egy lehetséges megoldás a kifejezőerő növekedésének problémájára eredhet a ténytudás és az észleléses illetve viselkedéses készségek megkülönböztetéséböl. E különbségtétel a filozófiában és a pszichológiában is jól ismert (pl. Carroll, 1895; Winch, 1990; Lewis, 1990; Baddeley \& mtsai, 2010, pp. 140-145). Pusztán tények megjegyzésével sohasem tanulhatunk meg kerékpározni, vagy zongorán játszani; mindkettőt gyakorolni kell. Végső soron kognitív képességeinkre is igaz ez: ahhoz, hogy valaki új és nehéz problémákat oldjon meg egy adott területen, egyszerübekkel kezdve kell gyakorolnia a feladatmegoldást, nem pusztán a már létező ismereteket bemagolnia (Surif \& mtsai, 2012). A készségtudás vagy procedurális tudás nem vezethető vissza ténytudásra, attól alapvetően eltér. A megismeréstudomány modelljeiben oly gyakran használt logikaiszimbolikus, kompozicionalitáson alapuló reprezentációk a ténytudást és annak kezelését ragadják meg; ugyanakkor a kombinációs és következtetési szabályok ismerete, megfelelö használata a procedurális tudás területére tartozik.

Hogyan járulhat hozzá e különbségtétel a fogalomtanulás megértéséhez? Mint láttuk, a fogalmaknak két alapvető funkciójuk van, a referencia és a tudástárolás (illetve utóbbi segítségével a következtetési rendszerünkbe való beépülés). A referencia rögzítéséhez ugyanakkor alapvetőek az észlelési és viselkedéses készségek, vagyis a procedurális tudás bizonyos fajtái. Ilyen például a fogalom tárgyának felismerése, szükség esetén megfelelö viselkedéses válasz produkálása (ha krokodil, akkor szaladjunk el, ha medve, akkor ne) kommunikációs készségek, mint információkérés („Megmutatnád, melyik a csiperke, és melyik a gyilkos galóca?”), készségek bemutatása („Nézd, így kell a körfürésszel vágni."), és hasonlók. Minthogy a procedurális tudás nem redukálható ténytudásra (sőt, alighanem annál alapvetőbb), ez a felismerés egyfajta általános megoldási keretet adhat a kifejezőerő növekedésének problémájára. A referálás készség; az új fogalmak tanulásában - ezen belül is a referencia rögzítésében - az észlelési és motoros készségtanulás nélkülözhetetlen szerepet játszik. Ez viszont túlmutat a megismerés illetve tanulás kompozicionális modelljein. Talán sokszor nem is vesszük észre, hogy egy-egy fogalom ismerete szempontjából a készségek alapvetőbbek, mint a definíció jellegü leírások. Egy gyors példa segíthet ezt megérteni. A REPÜLÖGÉP fogalmára tekintheünk úgy, mint egyfajta összetételre: a repülőgép egy olyan szerkezet, mely öneröből képes folyamatosan mozogva a levegőben maradni. Vajon e leírás megragadja-e a REPÜLŐGÉP fogalmát, mellyel ma már mindannyian rendelkezünk? Viszonylag könnyen belátható, hogy nem. A fizikus és matematikus Lord Kelvin által hangoztatott nézet, mely szerint „, $A$ levegönél nehezebb repülö eszközök nem lehetségesek”, szépen példázza ezt. Lord Kelvin elgondolta a repülőgép fenti meghatározását, ennek ellenére állításából nyilvánvaló, hogy fogalma sem volt róla, mi a repülőgép. Ahhoz, hogy valakinek erröl fogalma legyen, több tényezőre van szükség. Egyrészt a kulturális evolúció részeként a repülögépeket meg kell tervezni és építeni, bátor pilótáknak életük kockáztatásával kipróbálni a korai modelleket, és hasonlók. A fogalmat tanuló gyermek pedig ebbe a kulturális közegbe beleilleszkedve tanulja a releváns készségeket: látják, megtanulják megkülönböztetni 
a madaraktól és a helikopterektől, a szerencsésebbek felszállnak rá, és sokan játék repülömodellek segítségével szereznek további tapasztalatot. Ebbe a készség-keretbe természetesen a ténytudás is beleilleszthető, de önmagában, szenzomotoros tapasztalat és procedurális tanulás nélkül nem eredményez új fogalmat. Ez a megfigyelés elvezethet egy olyan elmélethez, mely szerint a fogalomtanulás és a kifejezöerö növekedésének alapja kulturálisan közvetített készségtanulás. Egy ilyen elmélet kifejtése azonban már egy következő cikk témája lehet.

\section{Irodalomjegyzék}

Backsheider, A., Markman, E., M. (1990). Young children's use of taxonomic assumption to constrain word meaning. Publikálatlan kézirat, Stanford University (hivatkozza: Markman, 1990).

Baddeley, A., Eysenck, M., W., Anderson, M., C. (2010). Emlékezet, Akadémiai Kiadó, Budapest

Barsalou, L., W. (1999). Perceptual symbol systems, Behavioral and Brain Sciences 22, 577-660. DOI: 10.1017/s0140525x99002149

Carey, S. (2009). The origin of concepts. New York NY: Oxford University Press. DOI: 10.1093/acprof:o so/9780195367638.001.0001

Carey, S. (2014). On Learning New Primitives in the Language of Thought: Reply to Rey, Mind \& Language, 29(2), 133-166. DOI: 10.1111/mila.12045

Carey, S. (2015). Why Theories of Concepts Should Not Ignore the Problem of Acquisition, in: Eric Margolis and Stephen Laurence (Eds.), The Conceptual Mind: New Directions in the Study of Concepts, Cambridge Mass.: The MIT Press

Carroll, L. (1895). What the Tortoise Said to Achilles. Mind, 4, 278-80. DOI: 10.1093/mind/iv.14.278

Clark, A. (1991): Microcognition: Philosophy, Cognitive Science, and Parallel Distributed Processing, Cambridge Mass. The MIT Press

Fodor, J. A. (1975). The Language of Thought. Cambridge MA: Harvard University Press.

Fodor, J. A. (1981). The present status of the innateness controversy. In Representations: philosophical essays on the foundations of cognitive science. Cambridge MA: MIT Press.

Fodor, J. A. (1990). A theory of content and other essays. Cambridge MA: MIT Press.

Fodor, J. A. (1998). Concepts: Where cognitive science went wrong. New York NY: Oxford University Press.

Fodor, J. A. (2008). LOT 2: The Language of Thought Revisited. New York NY: Oxford University Press.

Frege, G. (1974), The Foundations of Arithmetic, J. L. Austin (trans.), Oxford: Basil Blackwell.

Frege, G. (1967), The Basic Laws of Arithmetic, M. Furth (trans.), Berkeley: University of California.
Garson, J. (2016). Modal Logic, The Stanford Encyclopedia of Philosophy (Spring 2016 Edition), Edward N. Zalta (ed.), URL $=<$ https://plato.stanford. edu/archives/spr2016/entries/logic-modal/>.

Gelman, S., A. (2005). The Essential Child: Origins of Essentialism in Everyday Thought Oxford University Press

Goodman, N., \& Putnam, H. (1983). Fact, fiction, and forecast. Cambridge MA: Harvard University Press.

Jakab, Z. (2013). How to improve on Quinian bootstrapping - a response to nativist objections. In M. Knauff, M., Pauen, N., Sebanz, \& I. Wachsmuth (Eds.) Proceedings of the 35th Annual Conference of the Cognitive Science Society (pp. 639-645). Austin TX: Cognitive Science Society.

Johnson-Laird, P., N. (1986). Mental Models, Harvard University Press

Johnson-Laird, P., N. (2006) How We Reason. Oxford University Press. DOI: 10.1093/acprof:o so/9780199551330.001.0001

Keil, F., C. (1989). Concepts, Kinds, and Cognitive Development, Cambridge Mass. The MIT Press

Landau, B., Smith, L., B., Jones, S., S. (1988). The importance of shape in early lexical learning. Cognitive Development, 3, 299-321. DOI: 10.1016/0885-2014(88)90014-7

Laurence, S., \& Margolis, E. (2002). Radical concept nativism. Cognition, 86, 25-55. DOI: 10.1016/s00100277(02)00127-0

Lewis, D. (1990). What experience teaches. In G. W. Lycan (Ed.), Mind and Cognition. Hoboken, NJ: Wiley-Blackwell

MacDonald, C., MacDonald, G. (1995). Connectionism: Debates on Psychological Explanation, Oxford: Blackwell

Margolis, E. (1999). How to acquire a concept. In E.Margolis \& S. Laurence (Eds.), Concepts: Core readings. Cambridge MA: MIT Press.

Margolis, E., Laurence, S. (2011). Learning Matters: The Role of Learning in Cpncept Acquisition, Mind and Language, 26(5), 507-539. DOI: 10.1111/j.1468-0017.2011.01429.x 
Markman, E. (1990). Constraints Children Place on Word Meanings, Cognitive Science, 14, 57-77. DOI: $10.1207 / \mathrm{s} 15516709 \operatorname{cog} 140144$

Markman, E., M., Hutchinson, J., E. (1984). Children's sensitivity to constraints on word meaning: Taxonomic versus thematic relations. Cognitive Psychology, 16, 1-27. DOI: 10.1016/00100285(84)90002-1

Minsky, M. (1975). A Framework for Representing Knowledge, in: The Psychology of Computer Vision, ed. Patrick H. Winston). New York: McGraw-Hill.

Pinker, S. (1996). Language Learnability and Language Development, Cambridge Mass.: Harvard University Press

Pinker, S. (2006). A nyelvi ösztön, Typotex Kiadó

Platón (2013). Menón - Platón összes müvei kommentárokkal, Atlantisz Könyvkiadó

Putnam, H. (1975). The meaning of 'meaning', Minnesota Studies in the Philosophy of Science 7, 131-193

Putnam, H. (1981). Reason, truth, and history. Cambridge UK: Cambridge University Press.

Quine, W., V. O. (1960). Word and Object, MIT Press

Recanati, F. (2013). Mental Files, Oxford University Press. DOI: 10.1093/acprof:oso/9780199659982.001. 0001

Rey, G. 2014: Innate and learned: Carey, mad dog nativism, and the poverty of stimuli and analogies yet again, Mind \& Language, 29, 109-32. DOI: 10.1111/ mila. 12044

Rosch, E., H. (1975). Cognitive representation of semantic categories, Journal of Experimental Psychology: General, 104; 192-233. DOI: 10.1037//0096-3445.104.3.192

Rosch, E., H., Mervis, C., B. (1975). Family resemblances: studies in the internal structure of categories, Cognitive Psychology, 7; 573-605. DOI: 10.1016/0010-0285(75)90024-9

Rumelhart, D., E. (1980) Schemata: The Building Blocks of Cognition, In: Theoretical Issues in Reading Comprehension (ed. R. J. Spiro, Bertram C. Bruce, W. F. Brewer) Hillsdale, NJ: Erlbaum. DOI: 10.4324/9781315107493-4

Schank, R., C., Abelson, R., P. (1977). Scripts, Plans, Goals and Understanding: an Inquiry into Human Knowledge Structures, L. Erlbaum, Hillsdale, NJ. DOI: $10.4324 / 9780203781036$

Surif, J., Ibrahim, N., H., Mokhtar, M. (2012). Conceptual and Procedural Knowledge in Problem Solving, Procedia - Social and Behavioral Sciences 56, 416-425. DOI: 10.1016/j.sbspro.2012.09.671

Vajda, Pál (1943). Magyar feltalálók, Országos Közművelődési Szövetség

Winch, P. (1990). The idea of a social science and its relation to philosophy. London, UK: Routledge. DOI: 10.4324/9780203014493

\section{Jegyzetek}

1 Köszönet Kiss Szabolcsnak, aki erre a párhuzamra felhívta a figyelmemet.

2 A fogalmakra, Fodor és mások hagyományának megfelelően, nagybetűkkel hivatkozunk. A fogalmak a megismeréstudomány mai felfogása szerint mentállis reprezentációk, de nem természetes nyelvi kifejezések mentális reprezentációi, hanem azok jelentéséhez járulnak hozzá. Pékdául a ,holló', ,raven', ,гарван', ,gavran', ,corb', stb. szavak jelentését képező fogalom a HOLLÓ (természetesen irreleváns, hogy ezt a jelen cikk nyelve miatt magyarul írjuk ki: a ,holló' szó a világbasn repkedő madarakra, a ,HOLLÓ' betüsor meg az e madarakról a fejünkben kialakított belső modellre utal, függetlenül a beszélő anyanyelvétöl).

3 Érdekes módon maga Fodor nem tartotta ezt a felfogást teljes képtelenségnek. Egy alkalommal (2003 tavaszán) módom volt emailben is rákérdezni, és még a karburátor-példa sem ingatta meg innátista meggyőződésében; az imprinting példáját idézte válaszként. Később azonban felvázolt egy másfajta, de szintén biológiai mechanizmusokon alapuló fogalomelsajátítás-elméletet (Fodor, 2008; ennek megvitatásáról lásd Margolis \& Laurence, 2011).
4 Ha a szïkségszerü operátort bevezetjük, annak segítségével megadható a lehetséges definiíciója (ti. egy A állítás igazsága lehetséges akkor és csak akkor, ha A tagadása nem szükségszerüen igaz). A lehetésges, illetve szüikségszerü logikai operátorok müködése számos formális hasonlóságot mutat a predikátumlogika univerzális illetve egzisztenciális kvantoraival, ám szemantikai szempontból mégsem egyenértéküek (erről lásd Garson, 2016).

5 Felvethető, hogy például a konnekcionista neuronhálózat-modellek kivételt jelentenek ezalól az általánosítás alól, ám ez is azon múlik, hogy hogyan értelmezzük a konnekcionista rendszerek müködését (erről lásd: Clark, 1991; MacDonald \& MacDonald, 1995).

6 A fogalom tárgya a referencia. Kissé pontosabban fogalmazva: a tárgytípusokat jelölő általános fogalmaknak extenziójuk van; az extenzió a dolgok azon halmaza, melyre egy adott fogalmat alkalmazva igaz állítást kapunk (pl. a PORTÁS fogalmát az emberek egy részhalmazára alkalmazhatjuk helyesen). Referenciájuk a neveknek, illetve egyedi tárgyakat jelölö fogalmaknak van. 
7 A ,mentális mappa' kifejezés az angol ,mental file' fordítása.

8 Például „Oda nézzetek!”; „Ide gyorsan egy nyílvesszőt!”; „Ott megy a pecsenyénk!”, stb. A vadász 'pecsenyé'-t kiáltván utalhatna a nyúl hátsó combjára is, nem pedig az adott pillanatban látható egész, élö nyúlra.

${ }^{9}$ E kérdéskörről egy jó áttekintést ad Carey (2009, 4. fejezet).
10 A quine-i csizmahúzás elnevezése a nyelvelsajátítás kapcsán megfogalmazott ún. szemantikai csizmahúzásból ered, melynek során a gyerekek az örökletesen adottnak gondolt nyelvtani kategóriákat összekapcsolják az újonnan tanult szavakkal (Pinker, 1996, 2006). A szematikai és a Quine-féle csizmahúzás, mint kognitív folymaatok azonban alapvetően különböznek egymástól (erről lásd Carey, 2009, 8, 12. fejezet). 